\title{
Protocol development for somatic embryogenesis, SSR markers and genetic modification of Stipagrostis pennata (Trin.) De Winter
}

Masoumeh Asadi-Aghbolaghi ${ }^{1}$, Beata Dedicova ${ }^{2^{*}}$ (D), Sonali Sachi Ranade², Kim-Cuong Le ${ }^{2}$, Farzad Sharifzadeh ${ }^{1}$, Mansoor Omidi ${ }^{1}$ and Ulrika Egertsdotter ${ }^{2}$

\begin{abstract}
Background: Stipagrostis pennata (Trin.) De Winter is an important species for fixing sand in shifting and semi-fixed sandy lands, for grazing, and potentially as a source of lignocellulose fibres for pulp and paper industry. The seeds have low viability, which limits uses for revegetation. Somatic embryogenesis offers an alternative method for obtaining large numbers of plants from limited seed sources.

Results: A protocol for plant regeneration from somatic embryos of $S$. pennata was developed. Somatic embryogenesis was induced on Murashige \& Skoog (MS) medium supplemented with $3 \mathrm{mg} \cdot \mathrm{L}^{-1}$ 2,4-D subsequently shoots were induced on MS medium and supplemented with $5 \mathrm{mg} \cdot \mathrm{L}^{-1}$ zeatin riboside. The highest shoots induction was obtained when embryogenic callus derived from mature embryos (96\%) in combination with MS filter-sterilized medium was used from Khuzestan location. The genetic stability of regenerated plants was analysed using ten simple sequence repeats (SSR) markers from S. pennata which showed no somaclonal variation in regenerated plants from somatic embryos of S. pennata. The regenerated plants of $S$. pennata showed genetic stability without any somaclonal variation for the four pairs of primers that gave the expected amplicon sizes. This data seems very reliable as three of the PCR products belonged to the coding region of the genome.

Furthermore, stable expression of GUS was obtained after Agrobacterium-mediated transformation using a super binary vector carried by a bacterial strain LBA4404.

Conclusion: To our knowledge, the current work is the first attempt to develop an in vitro protocol for somatic embryogenesis including the SSR marker analyses of regenerated plants, and Agrobacterium-mediated transformation of S. pennata that can be used for its large-scale production for commercial purposes.
\end{abstract}

Keywords: Grass, Stipagrostis pennata (Trin.) De Winter, Somatic embryogenesis, Plant regeneration, SSR markers, Agrobacterium

\footnotetext{
*Correspondence: beata.dedicova@slu.se

${ }^{2}$ Department of Forest Genetics and Plant Physiology, Umeå Plant

Science Centre, Swedish University of Agricultural Sciences, 90183 Umeå, Sweden

Full list of author information is available at the end of the article
}

\section{Background}

Stipagrostis pennata (Trin.) De Winter belongs to the Poaceae subfamily Aristidoideae that holds only three genera (Aristida, Stipagrostis, and Sartidia) [1, 2]. S. pennata is a three-awned, perennial psammophytic grass common to desert areas in Iran, Afghanistan,

(c) The Author(s) 2021. This article is licensed under a Creative Commons Attribution 4.0 International License, which permits use, sharing, adaptation, distribution and reproduction in any medium or format, as long as you give appropriate credit to the original author(s) and the source, provide a link to the Creative Commons licence, and indicate if changes were made. The images or other third party material in this article are included in the article's Creative Commons licence, unless indicated otherwise in a credit line to the material. If material is not included in the article's Creative Commons licence and your intended use is not permitted by statutory regulation or exceeds the permitted use, you will need to obtain permission directly from the copyright holder. To view a copy of this licence, visit http://creativeco mmons.org/licenses/by/4.0/. The Creative Commons Public Domain Dedication waiver (http://creativecommons.org/publicdomain/ zero/1.0/) applies to the data made available in this article, unless otherwise stated in a credit line to the data. 
Turkmenistan, China, Saudi Arabia, and Iraq [3]. All known Stipagrostis species have a C4 photosynthetic pathway which enable them to survive in harsh and hot environments [4]. Furthermore, S. pennata has been shown to be able to host a microbiome that allows it to be a pioneer plant on nitrogen-deficient desert soils [5]. It is utilized for fixing sand in shifting and semi-fixed sandy lands, showing a strong tolerance to aridness, wind erosion, and sand embedding [6] and for grazing both in its green and dry stages, which makes this grass species important for landscaping and creating large pastures in arid and light sandy soils [7]. In Tunisia, Stipagrostis pungens is cultivated in large quantities as a source of lignocellulose fibres for pulp and paper industry [8]. The flowering and fruiting periods are usually from May until August, and the seeds are easy to cast [9]; however, the seeds show low viability and there is a shortage of plants for revegetation.

Clonal propagation by somatic embryogenesis offers an alternative propagation method with the potential to provide many plants from limited number of seeds. Protocols for somatic embryogenesis has been established for many valuable grass species like napiergrass (Pennisetum purpureum Schumach.) [10], reed grass (Phragites australis Cav.) [11]. Somatic embryogenesis also offers a platform technology for improving traits by genetic transformation and has been utilized for genetic transformation in millets [12] and switchgrass (Panicum virgatum L.) [13]. Furthermore, the model grass species Brachypodium distachyon has been frequently utilized for optimization of in vitro protocols and fundamental research [14]. To date, there are however no reports on somatic embryogenesis and genetic transformation in any species within the Aristidoideae subfamily.

Our work is the first attempt to develop an in vitro protocol for somatic embryogenesis of S. pennata, as well as testing the embryogenic callus for its competence to be genetically modified via Agrobacterium-mediated transformation. For both these technologies, the key question still remains, if the plants regenerated in vitro are genetically stable and they are not exhibiting any somaclonal variation described e.g. by D'Amato [15], Sree Ramulu et al. [16], Linacero et al. [17], Guo et al. [18] and Gao et al. [19]. Somaclonal variations are often observed in monocotyledonous and dicotyledonous species regenerated from different in vitro cultures. This genomic instability can be further analysed and confirmed by using techniques such as flow cytometry or by using molecular markers e.g. random amplified polymorphic DNA (RAPD) markers and simple sequence repeats (SSR) markers.

Microsatellites or simple sequence repeats (SSR) or short tandem repeats (STR) are molecular markers comprised of short repetitive DNA sequences of one to six nucleotides which result from mutations due to DNA polymerase slippage during replication and unequal recombination [20]. SSRs are highly polymorphic and their mutation rate is generally considered to be high $\left(10^{-2}\right.$ to $10^{-5}$ per locus per replication) as compared to that of single nucleotide polymorphisms (SNPs), and there are several advantages of SSRs over SNPs, the most important being the cost effectiveness and reliability [21]. SSRs are widely dispersed along the genome and are codominant, and also multi-allelic in nature; therefore SSRs are widely used as molecular markers in population genetics studies in plants which can be obtained by amplification the SSR containing regions by the PCR, once the primers are developed [22]. SSRs were used as molecular markers for analysis of genetic diversity and population structure in several cereal grass species e.g. pearl millet [23], rice [24], wheat [25], maize [26], barley [27], and rye [28]. SSRs have been also used to study the genetic structure in non-cereal grass species which are useful for foraging or paper/pulp industry or are of ecological and economical values such as bamboo [29], reed canary grass [30], guinea grass [31], Elymus nutans [32], ryegrass [33], buffalo grass [34], and centipede grass [35]. SSR transferability across species and sub-genera has been demonstrated by earlier studies in several plant genera e.g. Pinus [36], Cereus [37], Betula [38], and Hibiscus [39]. With reference to the Poaceae family, cross-species transferability of SSRs has been shown in sugarcane [40, 41], guinea grass [31], ryegrass [33], bamboo [42], and koronivia grass [43]. In plants, genetic changes that occur in mitotically dividing cells lead to somatic mutations, which are frequently caused by series of environmental factors [44]. Stress (biotic/abiotic) can also induce genome instability and somatic mutations in plants [45, 46]. Since the SSRs are highly polymorphic and their mutation rate is generally considered to be high, they can be used to analyse the genome stability, which is a cost effective way [47].

Agrobacterium-mediated transformation of monocotyledonous species has been for a long time technically challenging, especially for cereals [48, 49]. It took more than ten years after publishing the first successful Agrobacterium-mediated transformation of tobacco by De Block et al. [50] to produce the transgenic plants in crops such as rice [51], and maize [52]. Successful production of transgenic wheat and barley was done even later $[53,54]$. Despite the massive success in the area of usage of various transformation techniques and production of transgenic plants, its broad implementation for monocots species e.g. oats [55] and rye [56] still required improvements. Modifications and successful development of the existing transformation protocols including 


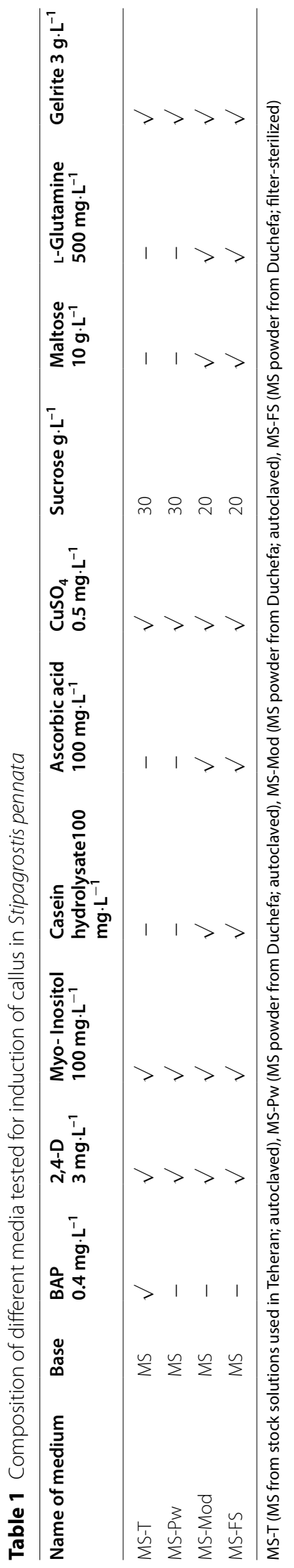


also completely new techniques and approaches [5761]. Moreover, there exists plant species such as grasses where this technique has not been tested effectively or widely implemented. One such species is $S$. pennata, where lack of reproducible and reliable protocol for plant regeneration via somatic embryogenesis has been a limiting factor for genetic modification. Our research was conducted to consider the effect of different callus induction media for formation of somatic embryos and genetic stability of regenerated in vitro plants.

\section{Methods}

Plant material and induction of somatic embryogenesis

Mature and immature caryopses of S. pennata were collected from field-grown, self-pollinated plants from two locations in Iran (Khuzestan $31^{\circ} 32^{\prime} 11.5^{\prime \prime} \mathrm{N}$ lat $49^{\circ} 03^{\prime}$ $04.3^{\prime \prime}$ E long; South Khorasan-32 $38^{\prime} 16.6^{\prime \prime} \mathrm{N}$ lat $59^{\circ} 05^{\prime}$ $15.7^{\prime \prime} \mathrm{E}$ long,). The seeds were surface sterilized with $70 \%$ ethanol for one min followed with $2 \%$ sodium hypochlorite for $10 \mathrm{~min}$ and rinsed by sterile Mili Q water three times. Four different explants were tested for callus induction and somatic embryos formation: cut caryopses, mature zygotic embryos, immature zygotic embryos, and leaf bases.

Caryopses after sterilization were transversely cut in halve. Mature and immature embryos $(0.5-2.0 \mathrm{~mm}$ long) were isolated under a stereomicroscope (Leica E4, Germany) and placed with the scutellum side up on callus induction medium. Leaf bases, we obtained by cutting lower part of young seedlings germinated on MS hormone free medium [62] for a week at $23{ }^{\circ} \mathrm{C}$ in the dark. All explants were cultured on MS callus induction medium (Table 1) with pH 5.6-5.8 adjusted before autoclaving or filter-sterilization $(0.2 \mu \mathrm{m})$. All cultures were grown in the dark at $23-25^{\circ} \mathrm{C}$.

\section{Plant regeneration and rooting}

After eight weeks, embryogenic calli with a creamy color and globular surface were transferred (approximately 20 pieces of calli per plate) onto shoot induction medium MS including salts and vitamins, supplemented with $5 \mathrm{mg} \cdot \mathrm{L}^{-1}$ zeatin riboside, $500 \mathrm{mg} \cdot \mathrm{L}^{-1} \mathrm{~L}$-glutamine, $100 \mathrm{mg} \cdot \mathrm{L}^{-1}$ casein hydrolysate, $100 \mathrm{mg} \cdot \mathrm{L}^{-1}$ ascorbic acid, $1.25 \mathrm{mg} \cdot \mathrm{L}^{-1} \mathrm{CuSO}_{4} \cdot 5 \mathrm{H}_{2} \mathrm{O}$ and $3 \%$ sucrose. $3 \%$ gelrite was used for media solidification and $\mathrm{pH}$ was adjusted to 5.6-5.8. Cultures were grown for $2-3$ weeks at $23-25{ }^{\circ} \mathrm{C}$ under continuous light at $40 \mu \mathrm{mol} \cdot \mathrm{m}^{-2} \cdot \mathrm{s}^{-1}$ in growth cabinet Percival (Percival Scientific, USA). Cultures were transferred to fresh medium every three weeks. When meristematic green zones appeared after the second sub-culture, cultures were transferred to fresh medium of the same composition and grown under light at $80 \mu \mathrm{mol} \cdot \mathrm{m}^{-2} \cdot \mathrm{s}^{-1}$ and a photoperiod of 16 -h photoperiod
(Grow Light Quattro, Venso EcoSolution, Finland). Welldeveloped elongated shoots were transferred to MS hormone-free medium, supplemented with $3 \%$ sucrose and grown for another $2-3$ weeks at $23{ }^{\circ} \mathrm{C}$ under 16 -h photoperiod under light at $80 \mu \mathrm{mol} \cdot \mathrm{m}^{-2} \cdot \mathrm{s}^{-1}$. Well-rooted plants were potted into Jiffy peat pots (Jiffy- $7^{\circledR}$ Norway), placed in plastic containers with green filters (COMBINESS \& Eco2NV, Belgium), and further grown in a controlled environment at $24{ }^{\circ} \mathrm{C}$ with a $16 / 8 \mathrm{~h}$ photoperiod for 5-6 weeks. When well-developed roots system had formed in the Jiffy pots, plants were transplanted to $1 \mathrm{~L}$ pots with regular greenhouse substrate and transferred to a greenhouse with controlled conditions (90\% humidity, $24{ }^{\circ} \mathrm{C}$, continuous light at $\left.100 \mu \mathrm{mol} \cdot \mathrm{m}^{-2} \cdot \mathrm{s}^{-1}\right)$.

\section{Data collection and statistical analyses}

Callus induction, somatic embryo induction and regeneration of shoots were carried out in four different media (Table 1) used for testing four different types of initial explants: cut caryopsis, mature embryo, immature embryo and leaf base, from two geographical locations (Khuzentan and South Khorasan) in Iran. Sixty explants were used in each experiment. Each treatment consisted of three replications and the experiment was repeated three times.

Shoot induction for all the explants was recorded after maintaining the cultures for eight weeks at $80 \mu \mathrm{mol} \cdot \mathrm{m}^{-}$ ${ }^{2} \cdot \mathrm{s}^{-1}$ and a photoperiod of $16-\mathrm{h}$. For statistical analyses, data were analysed by means of analyses of variance (ANOVA) using SAS (version 2.9). The treatments were grouped using the GLM Procedure (PROC GLM) method and analysed based on the Duncan's Multiple Range Test for means comparison at 5\% significance level. Graphs were plotted in Microsoft Excel.

\section{Histology}

Samples for histology were collected from all explants 21-28 days after culture initiation on callus induction medium and 20-40 days after transfer to shoot induction medium. The tissues were fixed overnight in formalin/acetic acid/alcohol (FAA; 50\% ethanol:10\% formalin:glacial acetic acid, 18:1:1). Fixed tissues were dehydrated in ethanol and tertiary-butanol series, and embedded in LR White resin [63]. Serial sections were cut at $5 \mu \mathrm{m}$ thickness on a rotatory microtome and stained with toluidine blue [64]. All sections were studied under light microscope (Axio Plan Imaging, Zeiss, Germany) and photographed with an attached camera (Axio Cam HRc, Zeiss, Germany).

\section{Somaclonal variation}

Genome stability (or absence of somaclonal variation) was evaluated in three samples of in vitro regenerated 
shoots of S. pennata obtained from tissue culture and four seedlings derived from zygotic seed germination were used as controls. DNA from fresh, young leaves was extracted using E.Z.N.A. ${ }^{\circledR}$ Plant DNA DS Kit (Omega) following manufacturer's instructions and DNA concentration was measured with Thermo 2000 Nanodrop. Ten pairs of SSR primers (Eurofins, Table 2) were selected based on the previous study on a closely related grass species (Stipa pennata) [65] as there is lack of any type of nucleotide sequence information available on the species of our interest. Polymerase Chain Reaction (PCR) was performed in 20 $\mu \mathrm{L}$ reaction mixture containing $50 \mathrm{ng}$ genomic DNA, $0.5 \mu \mathrm{M}$ of each primer (forward and reverse), $200 \mu \mathrm{M}$ dNTP (Thermo Scientific ${ }^{\mathrm{TM}}$ ), 2.5 units DreamTaq DNA Polymerase (Thermo Scientific ${ }^{\mathrm{TM}}$ ), 1X PCR buffer (10X buffer with $20 \mathrm{mM} \mathrm{MgCl}_{2}$ ) and $1 \mu \mathrm{L}$ Bovine Serum Albumin (BSA, $100 \mathrm{mg} \cdot \mathrm{mL}^{-1}$ stock). PCR conditions for all primers pairs were as follows: initial denaturation at $95{ }^{\circ} \mathrm{C}$ for $3 \mathrm{~min}$; 35 cycles of denaturation at $95{ }^{\circ} \mathrm{C}$ for $30 \mathrm{~s}$, annealing at $53{ }^{\circ} \mathrm{C}$ for $30 \mathrm{~s}$ and extension at $72{ }^{\circ} \mathrm{C}$ for $30 \mathrm{~s}$; final extension at $72{ }^{\circ} \mathrm{C}$ for $7 \mathrm{~min}$ PCR products were visualized on $3 \%$ agarose gel run with 0.5X TAE buffer, using $1 \mathrm{~Kb}$ DNA Ladder Plus (Thermo Scientific ${ }^{\mathrm{TM}}$ ) as marker.

\section{Bacterial strains used for transformation}

Agrobacterium tumefaciens strain LBA4404 harbouring a super binary plasmid was used for S. pennata transformation. This plasmid was carrying the $d s d A$ encoding D-serine ammonia lyase, from $E$. coli [66] as a plant selectable marker gene and a gus ( $\beta$-glucuronidase) reporter gene. Agrobacterium strain LBA4404 was prepared by inoculating a single colony from a freshly streaked LB plate in $20 \mathrm{~mL}$ of liquid LB medium [67]. The $A$. tumefaciens culture was supplemented with $50 \mu \mathrm{g} \cdot \mathrm{L}^{-1}$ spectinomycin and $60 \mu \mathrm{g} \cdot \mathrm{L}^{-1}$ rifampicin and was grown overnight in a rotatory shaker at $220-240 \mathrm{rpm}$ in darkness at $28{ }^{\circ} \mathrm{C}$ for 16-18 h. After measuring, the optical density of the cultures (O.D. 0.5-0.6) the bacterial culture was centrifuged at $4000 \mathrm{rpm}$ for $10 \mathrm{~min}$ and the supernatant was discarded. The bacterial pellet was then re-suspended in $20 \mathrm{~mL}$ of grass infection media [68] supplemented with $100 \mu \mathrm{M}$ of acetosyringone and culture was then incubated at $120 \mathrm{rpm}$ at $21^{\circ} \mathrm{C}$ in darkness for $1.5 \mathrm{~h}$.

\section{Tissue infection and GUS activity}

For plant tissue transformation experiments, a 3-dayold suspension culture of $S$. pennata embryogenic callus (from all four expalnts) was moved into liquid culture supplemented with $100 \mu \mathrm{M}$ of acetosyringone and mixed

Table 2 PCR primers used to analyze genomic stability of regenerated in vitro shoots obtained from embryogenic callus cultures of Stipagrostis pennata

\begin{tabular}{|c|c|c|c|c|}
\hline Primer & Primer sequences $\left(5^{\prime}-3^{\prime}\right)$ & Repeat motif & Allele size range & $\begin{array}{l}\text { GenBank } \\
\text { accession } \\
\text { no }\end{array}$ \\
\hline \multirow[t]{2}{*}{ Primer1 (SP10) } & F:CGCCTTTGTTGTTTATGAGCAG & $(\mathrm{TA})_{7}$ & $165-185$ & MG978348 \\
\hline & R:AGCTAGTGTCCCACGTGTC & & & \\
\hline \multirow[t]{2}{*}{ Primer2 (SP12) } & F:TAGATACGCCGGCTCGTT & $\mathrm{GCCC}_{4}$ & $401-420$ & MG978349 \\
\hline & R:GTGATGGCAAGTACGGCAG & & & \\
\hline \multirow[t]{2}{*}{ Primer3 (SP41) } & F:GGAAAGATGCGACAACCCG & $(\mathrm{GAA})_{4}$ & 412 & MG978355 \\
\hline & R:AACTTGAGCAGCCTCTTGG & & & \\
\hline \multirow[t]{2}{*}{ Primer4 (SP17) } & F:ACTGTTGAAACCACGATCCG & $(\mathrm{TAA})_{4}$ & $326-350$ & MG978351 \\
\hline & R:GCGGAACATTTGCCTTTGG & & & \\
\hline \multirow[t]{2}{*}{ Primer5 (SP43) } & F:GGCAGAACAAATGGAGCCC & $(\mathrm{AAT})_{4}$ & 323 & MG978356 \\
\hline & R:GCAAACGCATCGAAACCTC & & & \\
\hline \multirow[t]{2}{*}{ Primer6 (SP23) } & F:CTTAGCGCCTGGCCAAATC & $(\mathrm{TA})_{6}$ & 297-309 & MG978352 \\
\hline & R:CCTTTCCTGAAGCTAAACCGAC & & & \\
\hline \multirow[t]{2}{*}{ Primer7 (SP28) } & F:AGGCTCAGTGTCCGCAGAAG & $(\mathrm{TC})_{6}$ & $237-243$ & MG978353 \\
\hline & R:AGGCATAGCCAAATGCCAC & & & \\
\hline \multirow[t]{2}{*}{ Primer8 (SP30) } & F:AAAGCGGACGGCATTGTTC & $(\mathrm{TA})_{7}$ & 210 & MG978354 \\
\hline & R:AGAAAGCAAGCTTACGGTGC & & & \\
\hline \multirow[t]{2}{*}{ Primer9 (SP08) } & F:CCGGAAATACAATATCCTACCGC & $(\mathrm{CAA})_{3}$ & $288-297$ & MG968959 \\
\hline & R:GTCCGGAGGTCTCTCAAGG & & & \\
\hline \multirow[t]{2}{*}{ Primer10 (SP15) } & F:AGCGTAAAGCTCTCGAGTATG & $(\mathrm{TTA})_{4}$ & $413-430$ & MG978350 \\
\hline & R:CGAAGGGAGTCGCAAATTCAC & & & \\
\hline
\end{tabular}


with liquid Agrobacterium strains LBA4404 carrying a super binary construct pSB111AGUSSXA. The gus and $d s d A$ genes were driven by the maize ubiquitin 1 (Ubi1) promoter. The co-culture of the tissue with bacteria was carried out in the dark at $21{ }^{\circ} \mathrm{C}$ [58]. After three days of co-cultivation, bacterial growth was stopped by pouring the suspension through a Büchner funnel and washed with autoclaved distilled water supplemented with $500 \mathrm{mg} \cdot \mathrm{L}^{-1}$ cefotaxime. The callus cell suspension was plated on sterile filter paper and transferred onto the solid callus induction medium supplemented with $160 \mathrm{mg} \cdot \mathrm{L}^{-1}$ ticarcillin disodium/clavulanate potassium. Plant tissue was collected in a small tube approximately ten days after transformation for analysis of gus gene expression [69].

\section{Results}

\section{Embryogenic callus induction and plant regeneration}

Embryogenic callus could be induced from all tested $S$. pennata explants (cut caryopsis, isolated immature zygotic embryos, mature zygotic embryos, and leaf bases) followed by shoots regeneration and transfer of rooted in vitro plants to greenhouse (Fig. 1a-h). Media tested were prepared in two different ways, by autoclaving or filter sterilization. The detailed composition of media used see in Table 1.

Callus was induced from all four explants (cut caryopsis, isolated immature zygotic embryos, mature zygotic embryos, and leaf base) and appeared within one to two weeks. Callus was subcultured to fresh medium of the same composition every three weeks. Final scoring of callus induction was done after two sub-cultures to fresh medium and for the best responding explant type, mature embryos in combination with the filtersterilized medium from both geographic locations, (Khuzestan 100\% and South Korsahan 95\%; (Fig. 2a) were the best responding explant type. When the speed of callus induction was compared between the two geographic locations, all four types of explants originating from South Korsahan (cut caryopses required 18 days, mature embryos 9.3, immature embryos 18 and leaf base 17 days) they needed almost two times longer period for callus induction as compared to the explants originating from Khuzestan (Fig. 2b). From this graph, it is clear that long induction time was required on medium MS-T for cut caryopses (9.3 days), immature embryos (9.6 days) and for the leaf base ( 9 days). Mature isolated zygotic embryos responded much faster on medium MS-T (6.6 days). The embryogenic callus induction from all four explants derived from South Khorasan and for all the four media that were used,

(MS-T 64\%, MS-Pw 64\%, MS-Mod 67\% and MS-FS $77 \%)$ was lower in comparison to the ones derived from
Khuzestan (MS-T 84\%, MS-Pw 84\%, and MS-Mod 86\%; Fig. 2c). The highest embryogenic callus induction was observed when isolated mature zygotic embryos were grown on filter-sterilized (MS-FS 90\%) medium supplemented with 2,4-D, Casein hydrolysate, L-Glutamine, Copper sulphate $\left(\mathrm{CuSO}_{4}\right)$ and Ascorbic acid (Fig. 2c).

For shoot regeneration, MS filter-sterilized medium supplemented with $5 \mathrm{mg} \cdot \mathrm{L}^{-1}$ zeatin riboside was used in all our experiments for all explants. Embryogenic callus from South Khorasan responded on this medium with the highest shoot induction from mature embryos (73\%) and highest regeneration from leaf bases $(71 \%$; Fig. 2d). However, this response was still lower in comparison with the Khuzestan location. The highest shoot induction (96\%) was obtained when embryogenic callus derived from mature embryos in combination with MS filter-sterilized medium was used or MS-Mod medium with $93 \%$ shoots induction respectively.

From all these comparisons, we can conclude that for the Khuzestan location, mature zygotic embryos as explant for embryogenic callus induction followed by shoot regeneration using the filter-sterilized media could be recommended as the best combination in our experiments.

\section{Histological observations}

Mature and immature zygotic embryos approximately after 10-21 days in culture on callus induction medium started to produce compact and nodular callus, which is a typical characteristic for embryogenic callus in grasses. These nodular structures were often surrounded by a friable and translucent non-embryogenic callus. This stage of cultures with smooth, globular and pale yellow structures were fixed and embedded for the histological observation (Fig. 1c). Somatic embryos at different stage of development are visible in the sections stained with toluidine blue, proembryo structure (Fig. 1i) and globular embryos (Fig. $1 \mathrm{j}$ ) were visible. In the presence of high concentration of 2,4-D in the culture medium, the embryogenic nature of the callus can be maintained for some time. Frequent sub-culturing to the fresh medium (every two weeks) can help to continue with the embryogenic callus proliferation and development for up to two months (Fig. 1k). Once the embryogenic callus was transferred to shoot induction medium supplemented with $5 \mathrm{mg}$. $\mathrm{L}^{-1}$ zeatin riboside green, meristematic zone appeared in cultures and these structures were fixed and embedded in raisin for histological observations as well (Fig. 1d). When the cultures were transferred to medium with cytokinin in combination with the light culture conditions, then approximately 2-3 weeks later the green pockets in embryogenic callus were observed. Histological sections stained showed more advanced somatic 

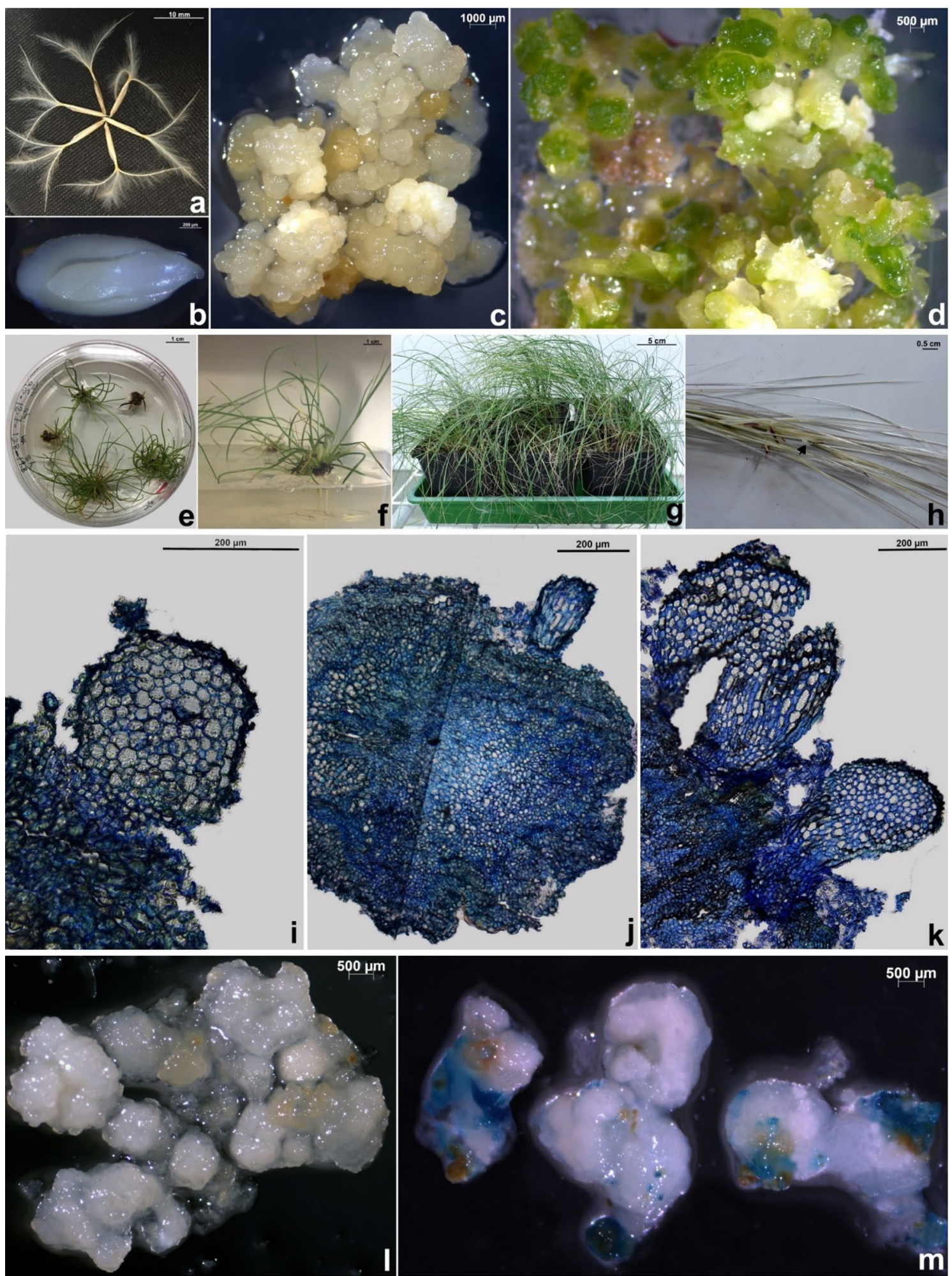

Fig. 1 Somatic embryogenesis of Stipagrostis pennata: a mature seeds, b zygotic embryo, c induction of embryogenic callus, $\mathbf{d}$ induction of shoot on MS medium supplemented with zeatin riboside, e elongation of shoot on MS hormone free medium $\mathbf{f}$ rooted in vitro plants on MS hormone free medium, $\mathbf{g}$ plants adapted in greenhouse, $\mathbf{h}$ spike with the flower; arrow is showing anthers and stigma, $\mathbf{i}$ section of preglobular somatic embryo stage stained with toluidine blue, $\mathbf{j}$ section of globular embryo, $\mathbf{k}$ section of emryoids an advanced stage of somatic embryo $\mathbf{I}$ control embryogenic callus for gus gene expression, $\mathbf{m}$ gus gene expression in embryogenic callus 
embryos formation and developed of meristematic shoot buds (Fig. 1k).

\section{SSR marker analysis}

For the current analysis, we tested 10 primer pairs (Table 2), out of which four primer pairs showed the expected size of amplification (Fig. 3): Primer1 showed a band size of $185 \mathrm{bp}$, Primer3 showed band size of $412 \mathrm{bp}$, Primer7 showed band size of $243 \mathrm{bp}$ and Primer8 showed band size of $210 \mathrm{bp}$. The control and regenerated samples showed similar amplification pattern for all the four primer pairs, which confirms that somatic mutations were not detected in the regenerated samples for the loci that were tested. The PCR with the remaining primer pairs did not show expected amplicon sizes while nonspecific amplification was observed in the control and regenerated samples.

\section{Agrobacterium-mediated transformation}

Embryogenic calli derived from different explants: cut caryopses, mature and immature embryos, as well as calli obtained from the leaf segments were assayed for GUS activity. Non-transformed embryogenic calli derived from immature embryos were used as control (Fig. 1l) and here no blue staining was observed, confirming that there is no endogenous GUS activity in the tissue. In contrast, the positive gus reporter gene expression and blue coloration of tissue were obtained in transformed embryogenic calli derived from cut caryopses (Fig. $1 \mathrm{~m}$ ). The results confirmed that bacterial strain LBA4404 carrying a construct with gus reporter gene can be used for genetic transformation of S. pennata embryogenic callus.

\section{Discussion}

In vitro plants regeneration and histological observations In grasses, the two major pathways for in vitro plant propagation through organogenesis and somatic embryogenesis were described in Gramineae already in the $80 \mathrm{~s}$ $[70,71]$. Immature embryos are commonly used as an explant for somatic embryos induction of maize [72], rice [73], wheat [74], barley [68], and also for a model grass species $[75,76]$.

The use of mature embryos was reported by Luo, 2004 for bentgrass [77] and leaf base from Panicum maximum Jacq. by Lu and Vasil, 1981 [78], and for Penisetum purpureum Schum. by Haydu and Vasil, 1981 [79].
Our results indicated that mature embryos were suitable explant for callus induction with following embryogenic callus formation as well with the subsequent shoots regeneration. Mature embryos from the Khuzestan location reached $100 \%$ callus induction $90 \%$ embryogenic callus induction, and $96 \%$ shoots regeneration in combination with filter-sterilized medium.

Mature embryos from the other location, South Korsahan showed $95 \%$ callus induction, $77 \%$ embryogenic callus induction and only $73 \%$ shoots regeneration. We just can speculate that these differences are due to the different geographical locations, age of the seeds and e.g. the storage condition of mature seeds.

Cut caryopses, immature embryos, and leaf base (Fig. 2) can induce embryogenic callus and regenerate plants but with lower frequencies and also they need more days to start with callus induction.

Leaf explants started the callus induction on the cut ends where friable callus was formed and later on an embryogenic callus appeared after subculture to the fresh medium (data not showed).

Many years of work in plant tissue culture indicated that 2,4-D is a key growth regulator for inducing somatic embryogenesis in dicots [80], monocots [81], and trees [82]. When we used MS medium supplemented with 2,4 and BAP (Table 1; original MS Teheran medium) callus and embryogenic callus induction, and subsequent shoots regeneration for all explants tested from both locations was lower. This medium was sterilized by autoclaving what can affect the final quality of induction media [83] including $\mathrm{pH}$ what can have an impact on the cellular morphology of cultures and regeneration capacity as well $[84,85]$.

Shoot meristems are either developed or organized de novo in callus cultures [86] or are produced by derepression of existing meristematic shoot primordia in in vitro cultures which consists largely of proliferating meristems [87]. Shoot meristems both ex vitro and in vitro are considered as multicellular in origin, can produce chimeras [88] and the formation of shoot meristems from callus cultures typically results in higher level of cytological anomalies (Fig. 3).

The embryogenic callus as well as suspension cultures are genetically and cytological stable, and usually do not give rise to chimeric plants [81, 89]. This statement has also been confirmed in our work by analyzing SSR markers in the S. pennata plants regenerated in vitro from somatic embryos. For embryogenic callus

(See figure on next page.)

Fig. 2 Responses from different initial explants of Stipagrostis pennata to embryogenic callus induction treatment. a Rate of callus induction, b days on induction medium before callus emergence, $\mathbf{c}$ embryogenic callus induction, $\mathbf{d}$ regeneration of shoots from two geographical locations (Khuzentan and South Khorasan) in Iran in four different media used for testing with four different types of explants (CS: cut caryopsis, ME: mature embryo, IME: immature embryo and LB: leaf base). Duncan's Test categories are indicated on the top of the bars 


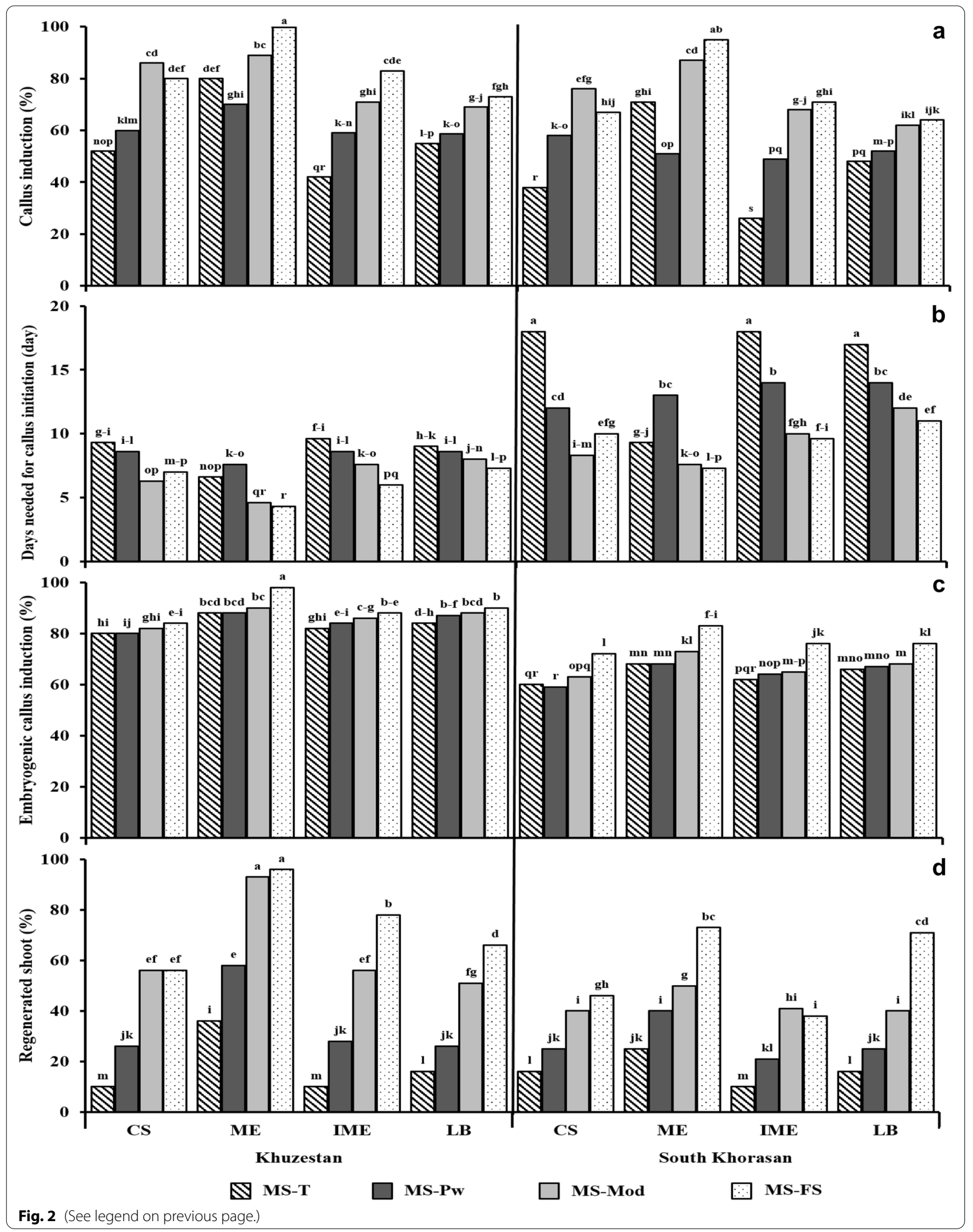




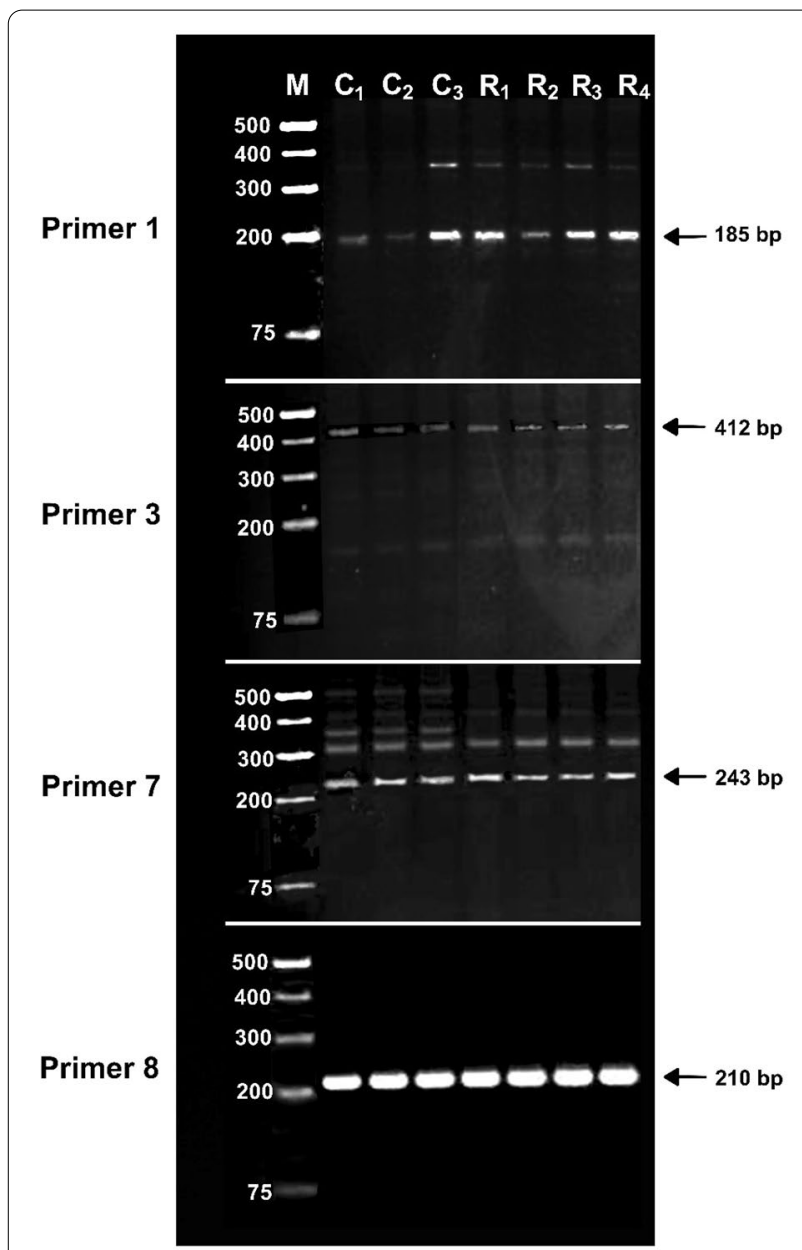

Fig. 3 Agarose gel (3\%) showing PCR amplification with the four SSR primers used for determining the genomic stability of the in vitro regenerated samples of Stipagrostis pennata $\left(R_{1}, R_{2}, R_{3}, R_{4}\right)$. Seedlings of $S$. pennata from zygotic seed germination were used as controls $\left(C_{1}, C_{2}, C_{3}\right)$. DNA marker is indicated by $M$

induction with subsequent plant regeneration in monocotyledon species e.g. rice, isolated immature zygotic embryos are typically the explant of choice $[73,74,90]$. Identical explants were also used for Brachypodium distachyon L. by Păcurar et al. [75] whereas the use of mature zygotic embryos as initial explants was reported by Luo et al. [77] in bentgrass. Our histological sections of embryogenic callus showed early stages of somatic pro embryos and emryoids development similar to somatic embryogenesis reported by Lu and Vasil (1985) [70, 91] for Panicum maximum (guinea grass).

Regenerated shoots on hormone-free MS medium easily formed roots and plants were successfully transferred to the soil wherein they were fully adapted to the controlled environment of the greenhouse in ex vivo condition, and they continued to grow.

\section{SSR marker analysis}

Genome stability during somatic embryogenesis has been accessed by analyzing SSR markers e.g. in pine [92], spruce [93] and oak [94]. Assessment of genetic stability with SSR markers has been demonstrated in micro propagated plants species [95, 96]; particularly in grasses with economical value e.g. sugarcane [97]. Genetic fidelity in regenerated sugarcane through direct organogenesis was determined with SSR markers [98]. In the current work, SSR markers were assessed to determine the genetic stability of the regenerated plants. PCR amplification of the expected size was observed in four out of the ten SSR markers that were tested. Polymorphism was not observed in the regenerated S. pennata plants when compared to the controls, which suggests that in vitro procedures did not cause any mutations in the regenerated plants and the regenerated plants thus have a genomic stability. Although polyacrylamide gels and capillary electrophoresis using fluorescence-labeled SSR markers are the methods used to confirm the variations in the microsatellites, agarose gel electrophoresis is also used as a standard technique to confirm the polymorphisms in the SSRs which has been successfully applied in agricultural crops like sweet cherry [99], olive [100] and rice $[101,102]$.

Primer1 and Primer7 primarily amplifies the expected sizes, although there are some low amplifications of nonspecific bands. These primers were originally designed for Stipa sp. which is a closely related species to S. pennata but yet a distinct species. Therefore, these primers seem to work for S. pennata, but also amplifies some other regions, which leads to higher band size. It is a worth to mention that there is lack of any type of nucleotide sequence information available for S. pennata, therefore primers designed for Stipa $s p$. were included for the current analysis.

The results from BLASTX performed with sequences of the PCR products of the respective primer pairs that showed the expected amplification size (GenBank accession numbers-Primer1: MG978348, Primer3: MG978355, Primer7: MG978353 and Primer8: MG978354) revealed that the Primer7 amplified sequence showed similarity with BSD domain-containing protein 1 gene. Primer1 and Primer8 PCR products showed similarity to hypothetical protein sequences. Thus three of the PCR products belonged to the coding region of the genome. Moreover, none of the regenerated samples showed somatic mutations in these coding sequences of the genome which suggests genomic stability in the coding parts for the loci analyzed. This reflects that the somatic embryogenesis procedures followed for the current work did not give rise to any somatic mutations for the loci tested and its worth 
mentioning that three of the loci tested belong to the coding region of the genome.

SSRs located in the coding regions are more relevant as compared to the ones that occur in the non-coding regions, primarily as the variations in the SSRs from coding regions would affect gene expression. Expressed sequence tags (ESTs) are potential candidates for development of genic SSR markers as well as applied for gene discovery, population genetic analysis and comparative genomic analysis [103]. Therefore, the EST-SSRs gained significant importance as "functional markers" that represent trueenetic diversity across the samples tested $[104,105]$. Several studies have been carried out to assess the genetic diversity among different species as well as different cultivars or populations using EST-SSRs [106, 107]. Particularly in grasses, EST-SSRs were assessed for genetic diversity analysis across and within species e.g. in bamboo [29], sugarcane [108], forage grass species [109], switchgrass [110], napiergrass [111] and, various species of temperate forage and turf grasses [112]. Moreover, the non-coding SSRs are poorly conserved across species [113], which is also evident from our current work. Out of the 10 pairs of the primers tested, which belong to Stipa pennata species, four primer pairs showed the expected size amplifications in the current species of interest (S. pennata) and three of the primer amplicons were located in the coding regions of the genome.

\section{Agrobacterium-mediated transformation}

Progress and challenges in Agrobacterium-mediated transformation in different grass species has been summarized by Giri and Praveena (2015) [114] and described in details for many grass species by different studies in bahiagrass (Paspalum notatum) [115, 116], rhodesgrass (Chloris gayana) [117], ruzigrass (Brachiaria ruziziensis) [118] and napiergrass (Pennisetum purpureum Schumach.) [76]. Gus (uidA) gene of Escherichia coli is the most widely used reporter gene to detect early steps of cell transformation, which was also successfully reported with reference to expression in turfgrass by Basu et al. (2004) [119] and by Luo et al. (2004) [77] in bentgrass. Our results, using embryogenic calli derived from cut caryopses of S. pennata testing GUS expression confirmed that "the blue gene" could be successfully used in this grass species as well. Similar results were obtained for callus induced from immature embryos of Brachypodium distachion [120], a model species for grasses.

\section{Conclusions}

Our tissue culture protocol, which is developed and described here for the grass species S. pennata, includes embryogenic callus induction with genetically stable shoot regeneration, rooting in vitro, and successful adaptation of plants to ex vivo, in a greenhouse environment. This work, together with the positive expression of gus gene detected in the embryogenic calli, forms a solid base for the future transgenic plant production for the particular grass species which is of commercial value.

\section{Acknowledgements}

We would like to acknowledge funding for M. Asadi-Aghbolaghi from the University of Tehran for her six months Ph.D. scholarship at UPSC, Umeå, Sweden and Professor O. Nilsson from UPSC, Sweden for providing the GUS construct.

\section{Authors' contributions}

MA-A: Investigation, Validation, Formal analysis, Visualization, Writing-Original draft, Funding acquisition. BD: Conceptualization, Methodology, Formal analysis, Supervision, Visualization, Project administration, Writing - Original draft, Writing—Review \& Editing. SSR: Conceptualization, Methodology, Formal analysis, Supervision, Visualization, Writing - Original draft, Writing—Review \& Editing K-CL: Investigation, Validation, Formal analysis, Visualization, WritingReview \& Editing. FS and MO: Methodology, Supervision, Funding for scholarship. UE: Conceptualization, Resources, Funding acquisition, Writing-Review \& Editing. All authors read and approved the final manuscript.

\section{Funding}

Open access funding provided by Swedish University of Agricultural Sciences. Funding for M. Asadi-Aghbolaghi from the University of Tehran for her six months Ph.D. scholarship at UPSC.

Availability of data and materials

All data generated or analyzed during this study are included in this published article.

\section{Declarations}

Ethics approval and consent to participate

Not applicable.

\section{Consent for publication}

Not applicable.

\section{Competing interests}

The authors declare that they have no conflict of interest.

\section{Author details}

${ }^{1}$ Department of Agronomy and Plant Breeding, College of Agriculture and Natural Resources, University of Tehran, 14174 Karaj, Iran. ${ }^{2}$ Department of Forest Genetics and Plant Physiology, Umeå Plant Science Centre, Swedish University of Agricultural Sciences, 90183 Umeå, Sweden.

Received: 1 March 2021 Accepted: 12 June 2021

Published online: 30 June 2021

References

1. Caro JA. Sinopsis taxonómica de las gramíneas argentinas. Dominguezia. 1982:4:1-51.

2. Group Grass Phylogeny Working, Barker NP, Clark LG, Davis JI, Duvall MR, Guala GF, et al. Phylogeny and subfamilial classification of the grasses (Poaceae). Ann Missouri Bot Gard. 2001;88:373-457. 
3. Freitag $\mathrm{H}$. Notes on the distribution, climate and flora of the sand deserts of Iran and Afghanistan. Proc R Soc Edinburgh Sect B Biol Sci. 1986;89:135-46.

4. Hattersley PW. C4 photosynthetic pathway variation in grasses (Poaceae): its significance for arid and semi-arid lands. In: Chapman GP, editor. Desertif Grasslands Their Biol Manag Linn Soc London. 1992. p. $181-212$.

5. Tian Y, Ma X, Li Y, Cheng C, Ge F, An D. Relationship between microbial diversity and nitrogenase activity of Stipagrostis pennata rhizosheath. J Cell Biochem. 2019;120:13501-8.

6. Yiti M. Biological and ecological characteristics of Aristida pennata. Arid Zo Res. 1990;7:52-6.

7. Moghimi J. Introduce of some important rangeland species of Iran. Arvan, Tehran, Iran; 2005. p. 300

8. Ferhi F, Das S, Moussaoui Y, Elaloui E, Yanez JG. Paper from Stipagrostis pungens. Ind Crops Prod. 2014;59:109-14.

9. Cei LR. Flora of Xinjiang 6. Urumqi Xinjiang Sci. Technol: Press; 1998.

10. Gondo T, Umami N, Muguerza M, Akashi R. Plant regeneration from embryogenic callus derived from shoot apices and production of transgenic plants by particle inflow gun in dwarf napier grass (Pennisetum purpureum Schumach). Plant Biotechnol. 2017;34:143-50.

11. Lauzer D, Dallaire S, Vincent $G$. In vitro propagation of reed grass by somatic embryogenesis. Plant Cell Tissue Organ Cult. 2000;60:229-34.

12. Sood P, Singh RK, Prasad M. Millets genetic engineering: the progress made and prospects for the future. Plant Cell Tissue Organ Cult. 2019;137:421-39.

13. Merrick P, Fei S. Plant regeneration and genetic transformation in switchgrass - a review. J Integr Agric. 2015;14:483-93.

14. Betekhtin A, Hus K, Rojek-Jelonek M, Kurczynska E, Nibau C, Doonan $\mathrm{JH}$, et al. In vitro tissue culture in Brachypodium: Applications and challenges. Int J Mol Sci. 2020;21:1037.

15. D'Amato F. The problem of genetic stability in plant tissue and cell cultures. Crop Genet Resour today tomorrow; pp. 338-48.

16. Sree Ramulu K, Dijkhuis P, Roest S, Bokelmann GS, De Groot B. Early occurence of genetic instability in protoplast cultures of potato. Plant Sci Lett. 1984;36:79-86.

17. Linacero R, Alves EF, Vázquez AM. Hot spots of DNA instability revealed through the study of somaclonal variation in rye. Theor Appl Genet. 2000;100:506-11.

18. Guo WL, Wu R, Zhang YF, Liu XM, Wang HY, Gong L, et al. Tissue cultureinduced locus-specific alteration in DNA methylation and its correlation with genetic variation in Codonopsis lanceolata Benth. et Hook. f. Plant Cell Rep. 2007;26:1297-307.

19. Gao DY, Vallejo VA, He B, Gai YC, Sun LH. Detection of DNA changes in somaclonal mutants of rice using SSR markers and transposon display. Plant Cell Tissue Organ Cult. 2009;98:187-96.

20. Levinson G, Gutman GA. Slipped-strand mispairing: a major mechanism for DNA sequence evolution. Mol Biol Evol. 1987;4:203-21.

21. Guichoux E, Lagache L, Wagner S, Chaumeil P, Léger P, Lepais O, et al. Current trends in microsatellite genotyping. Mol Ecol Resour. 2011:11:591-611.

22. Varshney RK, Graner A, Sorrells ME. Genic microsatellite markers in plants: features and applications. Trends Biotechnol. 2005;23:48-55.

23. Adeoti K, Djedatin G, Ewedje E, Beulé T, Santoni R, Rival A, et al. Assessment of genetic diversity among cultivated Pearl millet (Pennisetum glaucum, Poaceae) accessions from Benin West Africa. Afr J Biotechnol. 2017;16:782-90

24. Suvi WT, Shimelis H, Laing M, Mathew I, Shayanowako AIT. Assessment of the genetic diversity and population structure of rice genotypes using SSR markers. Acta Agric Scand Sect B Soil Plant Sci. 2020;70:76-86.

25. Knapp S, Döring TF, Jones HE, Snape J, Wingen LU, Wolfe MS, et al. Natural selection towards wild-type in composite cross populations of winter wheat. Front Plant Sci. 2020;10:1757.

26. Adu GB, Awuku FJ, Amegbor IK, Haruna A, Manigben KA, Aboyadana PA. Genetic characterization and population structure of maize populations using SSR markers. Ann Agric Sci. 2019;64:47-54.

27. Ferreira JR, Pereira JF, Turchetto C, Minella E, Consoli L, Delatorre CA. Assessment of genetic diversity in Brazilian barley using SSR markers. Genet Mol Biol. 2016;39:86-96
28. Shang HY, Wei YM, Wang XR, Zheng YL. Genetic diversity and phylogenetic relationships in the rye genus Secale L. (rye) based on Secale cereale microsatellite markers. Genet Mol Biol . 2006:29:685-91.

29. Cai K, Zhu L, Zhang K, Li L, Zhao Z, Zeng W, et al. Development and characterization of EST-SSR markers from RNA-Seq data in phyllostachys violascens. Front Plant Sci. 2019;10:50

30. Barth S, Jankowska MJ, Hodkinson TR, Vellani T, Klaas M. Variation in sequences containing microsatellite motifs in the perennial biomass and forage grass, Phalaris arundinacea (Poaceae). BMC Res Notes. 2016;9:184.

31. Sousa ACB, Jungmann L, Campos T, Sforça DA, Boaventura LR, Silva GMB, et al. Development of microsatellite markers in Guineagrass (Panicum maximum Jacq.) and their transferability to other tropical forage grass species. Plant Breed. 2011;130:104-8.

32. Chen $S$, Zhang $X, M a X$, Huang L. Assessment of genetic diversity and differentiation of Elymus nutans indigenous to Qinghai-Tibet Plateau using simple sequence repeats markers. Can J Plant Sci. 2013:93:1089-96.

33. Guo ZH, Fu KX, Zhang XQ, Zhang CL, Sun M, Huang T, et al. SSRs transferability and genetic diversity of three allogamous ryegrass species. Comptes Rendus - Biol. 2016;339:60-7.

34. Hadle JJ, Konrade LA, Beasley RR, Lance SL, Jones KL, Beck JB. Development of microsatellite markers for buffalograss (Buchloë dactyloides; Poaceae), a drought-tolerant turfgrass alternative. Appl Plant Sci. 2016:4:1600033.

35. Li J, Guo H, Wang Y, Zong J, Chen J, Li D, et al. High-throughput SSR marker development and its application in a centipedegrass (Eremochloa ophiuroides (Munro) Hack) genetic diversity analysis. PLOS ONE. 2018;13:e0202605.

36. Chagné D, Chaumeil P, Ramboer A, Collada C, Guevara A, Cervera MT, et al. Cross-species transferability and mapping of genomic and CDNA SSRs in pines. Theor Appl Genet. 2004;109:1204-14.

37. Bombonato JR, Bonatelli IAS, Silva GAR, Moraes EM, Zappi DC, Taylor NP, et al. Cross-genera SSR transferability in cacti revealed by a case study using cereus (Cereeae, cactaceae). Genet Mol Biol. 2019:42:87-94.

38. Gürcan $\mathrm{K}$, Mehlenbacher SA. Transferability of microsatellite markers in the betulaceae. J Am Soc Hortic Sci. 2010;135:159-73.

39. Kim JM, Lyu JI, Lee MK, Kim DG, Kim JB, Ha BK, et al. Cross-species transferability of EST-SSR markers derived from the transcriptome of kenaf (Hibiscus cannabinus L.) and their application to genus Hibiscus. Genet Resour Crop Evol. 2019;66:1543-56.

40. UI Haq S, Kumar P, Singh RK, Verma KS, Bhatt R, Sharma M, et al. Assessment of functional est-ssr markers (sugarcane) in cross-species transferability, genetic diversity among poaceae plants, and bulk segregation analysis. Genet Res Int. 2016; 2016:1-17.

41. Singh RB, Mahenderakar MD, Jugran AK, Singh RK, Srivastava RK. Assessing genetic diversity and population structure of sugarcane cultivars, progenitor species and genera using microsatellite (SSR) markers. Gene. 2020:753(144800):1-13.

42. Lin Y, Lu JJ, Wu MD, Zhou MB, Fang W, Ide Y, et al. Identification, crosstaxon transferability and application of full-length CDNA SSR markers in Phyllostachys pubescens. Springerplus. 2014;3:486.

43. Vigna BBZ, Alleoni GC, Jungmann L, Do Valle CB, De Souza AP. New microsatellite markers developed from Urochloa humidicola (Poaceae) and cross amplification in different Urochloa species. BMC Res Notes. 2011:4:523.

44. Schoen DJ, Schultz ST. Somatic mutation and evolution in plants. Annu Rev Ecol Evol Syst. 2019;50:49-73.

45. Kovalchuk I, Kovalchuk O, Kalck V, Boyko V, Filkowski J, Heinlein M, et al. Pathogen-induced systemic plant signal triggers DNA rearrangements. Nature. 2003:423:760-2

46. Yao Y, Kovalchuk I. Abiotic stress leads to somatic and heritable changes in homologous recombination frequency, point mutation frequency and microsatellite stability in Arabidopsis plants. Mutat Res - Fundam Mol Mech Mutagen. 2011;707:61-6.

47. Ranade SS, Ganea LS, Razzak AM, García Gil MR. Fungal infection increases the rate of somatic mutation in scots pine (Pinus sylvestris L.). J Hered. 2015:106:386-94.

48. McElroy D, Louwerse JD, McElroy SM, Lemaux PG. Development of a simple transient assay for Ac/Ds activity in cells of intact barley tissue. Plant J. 1997:11:157-65. 
49. Hensel G. Genetic transformation of triticeae cereals for molecular farming. Genet Transform. 2011;1:171-90.

50. De Block M, Botterman J, Vandewiele M, Dockx J, Thoen C, Gosselé $\checkmark$, et al. Engineering herbicide resistance in plants by expression of a detoxifying enzyme. EMBO J. 1987;6:2513-8.

51. Chan MT, Chang HH, Ho SL, Tong WF, Yu SM. Agrobacterium-mediated production of transgenic rice plants expressing a chimeric a-amylase promoter/B-glucuronidase gene. Plant Mol Biol. 1993;22:491-506.

52. Ishida Y, Saito H, Ohta S, Hiei Y, Komari T, Kumashiro T. High efficiency transformation of maize (Zea mays L.) mediated by Agrobacterium tumefaciens. Nat Biotechnol. 1996;14:745-50.

53. Cheng M, Fry JE, Pang S, Zhou H, Hironaka CM, Duncan DR, et al. Genetic transformation of wheat mediated by Agrobacterium tumefaciens. Plant Physiol Am Soc Plant Biol. 1997;115:971-80.

54. Tingay S, McElroy D, Kalla R, Fieg S, Wang M, Thornton S, et al. Agrobacterium tumefaciens-mediated barley transformation. Plant J. 1997;11:1369-76.

55. Gasparis S, Bregier C, Orczyk W, Nadolska-Orczyk A. Agrobacteriummediated transformation of oat (Avena sativa $\mathrm{L}$ ) cultivars via immature embryo and leaf explants. Plant Cell Rep. 2008;27:1721-9.

56. Popelka JC, Altpeter F. Agrobacterium tumefaciens-mediated genetic transformation of rye (Secale cereale L.). Mol Breed. 2003;11:203-11.

57. Dedicova B, Bermudez C, Prias M, Zuniga E, Brondani C. High-throughput transformation pipeline for a Brazilian japonica rice with bar gene selection. Protoplasma. 2015;252:1071-83.

58. Zuniga-Soto E, Mullins E, Dedicova B. Ensifer-mediated transformation: an efficient non-Agrobacterium protocol for the genetic modification of rice. Springerplus. 2015;4:1-10

59. Puchta H. Applying CRISPR/Cas for genome engineering in plants: the best is yet to come. Curr Opin Plant Biol. 2017;36:1-8.

60. Demirer GS, Zhang H, Matos JL, Goh NS, Cunningham FJ, Sung Y, et al. High aspect ratio nanomaterials enable delivery of functional genetic material without DNA integration in mature plants. Nat Nanotechnol. 2019;14:456-64

61. Dalton SJ. A reformulation of Murashige and Skoog medium (WPBS medium) improves embryogenesis, morphogenesis and transformation efficiency in temperate and tropical grasses and cereals. Plant Cell Tissue Organ Cult. 2020;141:257-73.

62. Murashige T, Skoog F. A revised medium for rapid growth and bio assays with tobacco tissue cultures. Physiol Plant. 1962:15:473-97.

63. Newman GR, Jasani B, Williams ED. The preservation of ultrastructure and antigenicity. J Microsc. 1982:127:5-6.

64. Sakai WS. Simple method for differential staining of paraffin embedded plant material using toluidine blue o. Biotech Histochem. 1973:48:247-9.

65. Klichowska E, Ślipiko M, Nobis M, Szczecińska M. Development and characterization of microsatellite markers for endangered species Stipa pennata (Poaceae) and their usefulness in intraspecific delimitation. Mol Biol Rep. 2018:45:639-43.

66. Erikson $\mathrm{O}$, Hertzberg M, Näsholm T. The dsdA gene form Escherichia coli provides a novel selectable marjer for plant transformation. Plant Mol Biol. 2005;57:452-433.

67. Bertani G. Studies on lysogenesis. I. The mode of phage liberation by lysogenic Escherichia coli. J Bacteriol. 1951;62:293-300.

68. Trifonova A, Dedicova B, Mankin, L. D-Amino acid selectable marker for barley (Hordeum vulgare L.); 2009; US 2009/0300800 A1.

69. Jefferson RA, Kavanagh TA, Bevan MW. GUS fusions: beta-glucuronidase as a sensitive and versatile gene fusion marker in higher plants. EMBO J. 1987:6:3901-7.

70. Lu C-Y, Vasil Indra K. Histology of somatic embryogenesis in Panicum maximum (Guinea grass). Am J. 1985;72:1908-13.

71. Vasil IK. Somatic embryogenesis and its consequences in the gramineae. Tissue Cult For Agric. 1985;1:31-47.

72. Lu C, Vasil IK, Ozias-Akins P. Somatic embryogenesis in Zea mays L. Theor Appl Genet. 1982;62:109-12.

73. Hiei Y, Komari T. Improved protocols for transformation of indica rice mediated by Agrobacterium tumefaciens. Plant Cell Tissue Organ Cult. 2006:85:271-83.

74. Ishida Y, Hiei Y, Komari T. High efficiency wheat transformation mediated by Agrobacterium tumefaciens. Adv Wheat Genet From Genome to F. Springer, Tokyo; 2015. p. 167-73.
75. Păcurar DI, Thordal-Christensen H, Nielsen KK, Lenk I. A highthroughput Agrobacterium-mediated transformation system for the grass model species Brachypodium distachyon L. Transgenic Res. 2008; 17:965-75.

76. Ishigaki G, Gondo T, Suenaga K, Akashi R. Fertile transgenic Brachiaria ruziziensis (ruzigrass) plants by particle bombardment of tetraploidized callus. J Plant Physiol. 2012:169:546-9.

77. Luo H, Hu Q, Nelson K, Longo C, Kausch AP, Chandlee JM, et al. Agrobacterium tumefaciens-mediated creeping bentgrass (Agrostis stolonifera L.) transformation using phosphinothricin selection results in a high frequency of single-copy transgene integration. Plant Cell Rep. 2004;22:645-52.

78. Lu C, Vasil IK. Somatic embryogenesis and plant regeneration from leaf tissues of Panicum maximum Jacg. Theor Appl Gnetic. 1981;59:275-80.

79. Haydu Z, Vasil IK. Somatic embryogenesis and plant regeneration from leaf tissue and anthers of Pennisetum purpureum Schum. Theor Appl Genet. 1981;59:269-73.

80. Lo Schiavo F. Early events in emryogenesis. In: Bajaj YPS, editor. Biotechnology in Agriculture and Forestry. New York: Spriger; 1995. p. 20-9.

81. Vasil IK. Regeneration of plants from singke cells of cereals and grasess. In: Genetic Engineering in Eucaryot, vol; 1983. 61. p. 233-51.

82. von Arnold S, Sabala I, Bozhkov P, Dyachok J, Filonova L. Developmental pathway of somatic emryogenesis. PCTOC. 2002;69:232-49.

83. Schenk N, Hsiao K-C, Bornman CH. Avoidance of precipitation and carbohydrate breakdown in autoclaved plant tissue culture media. Plant Cell Rep. 1999;10:115-9.

84. Smith DL, Krikorian AD. Somatic embryogenesis of carrot in hormonefree medium: external pH control over morphogeneis. Am J Bot. 1990:77:1634-47.

85. Smith DL, Krikorian AD. Low external pH prevets cell elongation but not multiplication of embryogenic carrot cells. Physiol Plant. 1992;84:495-501.

86. Green C. In vitro plant regeneration in cereals and grasses. In:Thorpe T, editor. Front Plant Tissues Cult. Univ. of Calgary; 1978. p. 411-8.

87. Dunstan DI, Short KC, Dhaliwal H, Thomas E. Further studies on plantlet production from cultured tissues of Sorghum bicolor. Protoplasma. 1979;101:355-61.

88. Bennici A, Damato F. In vitro regeneration of durum wheat plants. 1. Chromosome numbers of regenerated plantlets. Z Pflanzenzüchtg. 1978:81:305-11.

89. Karp A, Maddock SE. Chromosome variation in wheat plants regenerated from cultured immature embryos. Theor Appl Genet. 1984;67:249-55

90. Luo Y, Wang F, Mu X, Kang Z, Gao H, Wang X. Optimization of transient expression of GUS after DNA delivery into wheat calli and leaves. J Biotech Res. 2019;10:50-8.

91. Marum L, Rocheta M, Maroco J, Oliveira MM, Miguel C. Analysis of genetic stability at SSR loci during somatic embryogenesis in maritime pine (Pinus pinaster). Plant Cell Rep. 2009;28:673-82.

92. Ho W-J, Vasil Indra K. Somatic embryogenesis in Sugarcane (Saccharum officinarum L.) I the Morphology and physiology of callus formation and the onthogeny of somatic embryos. Protoplasma. 1983;118:169-80.

93. Helmersson A, Von Arnold S, Burg K, Bozhkov PV. High stability of nuclear microsatellite loci during the early stages of somatic embryogenesis in Norway spruce. Tree Physiol. 2004;24:1181-6.

94. Lopes T, Pinto G, Loureiro J, Costa A, Santos C. Determination of genetic stability in long-term somatic embryogenic cultures and derived plantlets of cork oak using microsatellite markers. Tree Physiol. 2006;26:1145-52.

95. Brito G, Lopes T, Loureiro J, Rodriguez E, Santos C. Assessment of genetic stability of two micropropagated wild olive species using flow cytometry and microsatellite markers. Trees - Struct Funct. 2010;24:723-32.

96. Kumar M, Kumari P, Gupta V, Reddy CRK, Jha B. Biochemical responses of red alga Gracilaria corticata (Gracilariales, Rhodophyta) to salinity induced oxidative stress. J Exp Mar Bio Ecol. 2010; 319:27-34.

97. Tiwari AK, Mishra N, Tripathi S, Lal M, Singh RK, Sharma ML. Assessment of genetic stability in micro propagated population of sugarcane variety CoS 07250 through SSR markers. Vegetos Soc Plant Res. 2011:24:75-81. 
98. Pandey RN, Singh SP, Rastogi J, Sharma ML, Singh RK. Early assessment of genetic fidelity in sugarcane (Saccharum officinarum) plantlets regenerated through direct organogenesis with RAPD and SSR markers. Aust J Crop Sci. 2012;6:618-24.

99. Ercisli S, Agar G, Yildirim N, Duralija B, Vokurka A, Karlidag H. Genetic diversity in wild sweet cherries (Prunus avium) in Turkey revealed by SSR markers. Genet Mol Res. 2011:10:1211-9.

100. Montemurro C, Simeone R, Pasqualone A, Ferrara E, Blanco A. Genetic relationships and cultivar identification among 112 olive accessions using AFLP and SSR markers. J Hortic Sci Biotechnol. 2005;80:105-10.

101. Ashkani S, Rafii MY, Rusli I, Sariah M, Abdullah SNA, Rahim HA, et al. SSRs for marker-assisted selection for blast resistance in rice (Oryza sativa L.). Plant Mol Biol Report. 2012;30:79-86.

102. Singh H, Deshmukh RK, Singh A, Singh AK, Gaikwad K, Sharma TR, et al. Highly variable SSR markers suitable for rice genotyping using agarose gels. Mol Breed. 2010;25:359-64.

103. Ellis JR, Burke JM. EST-SSRs as a resource for population genetic analyses. Heredity (Edinb). 2007;99:125-32.

104. Eujayl I, Sorrells ME, Baum M, Wolters P, Powell W. Isolation of ESTderived microsatellite markers for genotyping the $A$ and $B$ genomes of wheat. Theor Appl Genet. 2002;104:399-407.

105. Thiel T, Michalek W, Varshney RK, Graner A. Exploiting EST databases for the development and characterization of gene-derived SSR-markers in barley (Hordeum vulgare L.). Theor Appl Genet. 2003;106:411-22.

106. Choudhary S, Sethy NK, Shokeen B, Bhatia S. Development of chickpea EST-SSR markers and analysis of allelic variation across related species. Theor Appl Genet. 2009;118:591-608.

107. Wang X, Chen W, Luo J, Yao Z, Yu Q, Wang Y, et al. Development of ESTSSR markers and their application in an analysis of the genetic diversity of the endangered species Magnolia sinostellata. Mol Genet Genomics. 2019:294:135-47.

108. Zhang Z, Xie W, Zhao Y, Zhang J, Wang N, Ntakirutimana F, et al. EST-SSR marker development based on RNA-sequencing of E. sibiricus and its application for phylogenetic relationships analysis of seventeen Elymus species. BMC Plant Biol. 2019;19:235.

109. Singh RB, Singh B, Singh RK. Cross-taxon transferability of sugarcane expressed sequence tags derived microsatellite (EST-SSR) markers across the related cereal grasses. J Plant Biochem Biotechnol. 2019;28:176-88
110. Mian MAR, Saha MC, Hopkins AA, Wang ZY. Use of tall fescue EST-SSR markers in phylogenetic analysis of cool-season forage grasses. Genome. 2005;48:637-47.

111. Narasimhamoorthy B, Saha MC, Swaller T, Bouton JH. Genetic diversity in switchgrass collections assessed by EST-SSR markers. BioEnergy Res. 2008;1:136.

112. Negawo AT, Jorge A, Hanson J, Teshome A, Muktar MS, Azevedo ALS, et al. Molecular markers as a tool for germplasm acquisition to enhance the genetic diversity of a Napier grass (Cenchrus purpureus syn. Pennisetum purpureum) collection. Trop Grasslands-Forrajes Trop. 2018;6:58-69.

113. Kirigwi FM, Zwonitzer JC, Mian MAR, Wang ZY, Saha MC. Microsatellite markers and genetic diversity assessment in Lolium temulentum. Genet Resour Crop Evol. 2008;55:105-14.

114. Brown GR, Kadel EE, Bassoni DL, Kiehne KL, Temesgen B, Van Buijtenen $J$, et al. Anchored reference loci in loblolly pine (Pinus taeda L.) for integrating pine genomics. Genetics. 2001;159:799-809.

115. Gondo T, Tsuruta SI, Akashi R, Kawamura O, Hoffmann F. Green, herbicide-resistant plants by particle inflow gun-mediated gene transfer to diploid bahiagrass (Paspalum notatum). J Plant Physiol. 2005;162:1367-75.

116. Giri CC, Praveena M. In vitro regeneration, somatic hybridization and genetic transformation studies: an appraisal on biotechnological interventions in grasses. Plant Cell Tissue Organ Cult. 2015;120:843-60.

117. Himuro Y, Gondo T, Yamakawa K, Akashi R. Genetic transformation of bahiagrass (Paspalum notatum Flügge) by visually screening cells expressing green fluorescent protein. GrassI Sci. 2009;55:216-20.

118. Gondo T, Matsumoto J, Tsuruta S, Yoshida M, Kawakami A, Terami F, et al. Particle inflow gun-mediated transformation of multiple-shoot clumps in rhodes grass (Chloris gayana). J Plant Physiol. 2009;166:435-41.

119. Basu C, Kausch AP, Chandlee JM. Use of $\beta$-glucuronidase reporter gene for gene expression analysis in turfgrasses. Biochem Biophys Res Commun. 2004;320:7-10.

120. Draper J, Mur LAJ, Jenkins G, Ghosh-Biswas GC, Bablak P, Hasterok R, et al. Brachypodium distachyon. A new model system for functional genomics in grasses. Plant Physiol Am Soc Plant Biol. 2001;127:1539-55.

\section{Publisher's Note}

Springer Nature remains neutral with regard to jurisdictional claims in published maps and institutional affiliations.
Ready to submit your research? Choose BMC and benefit from:

- fast, convenient online submission

- thorough peer review by experienced researchers in your field

- rapid publication on acceptance

- support for research data, including large and complex data types

- gold Open Access which fosters wider collaboration and increased citations

- maximum visibility for your research: over $100 \mathrm{M}$ website views per year

At BMC, research is always in progress.

Learn more biomedcentral.com/submissions 